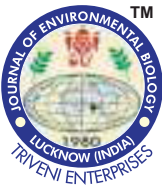

\title{
Impact of offshore aquaculture on molluscan biodiversity in Ildır Bay, Aegean Sea, Turkey
}

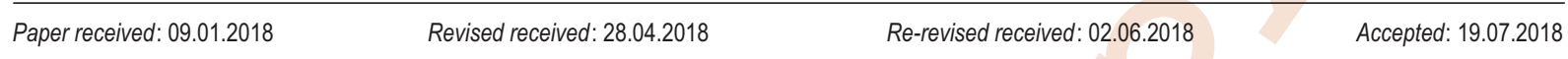

\section{Authors Info \\ M. Culha*, H. Somek and O. Aksoy \\ Department of Hydrobiology, Faculty of Fisheries, Izmir Katip Celebi University, Izmir, 35620, Turkey}

*Corresponding Author Email : msculha@gmail.com

\section{Edited by \\ Dr. R. B. Raizada}

Reviewed by

Dr. Pravata Pradhan

Dr. Zeqir Veselaj

\section{Abstract}

Aim : Benthic organisms in marine sediments affect several processes in which seas and oceans are very important. These organisms can represent the biodiversity, alive composition, biomass and prolificacy of the associated biota. The aim of this study was to determine the environmental effects of offshore aquaculture systems based on macrobenthic mollusc composition and the structure of its community in lldır Bay during specific spatial and temporal patterns.

Methodology : The benthic samplings of the zoobenthic organisms in the region were performed by means of Van Veen grab (10 I) from the sea sediment. In the laboratory, macrobenthic organisms were separated into main taxonomic groups. Various statistical methods were applied to establish the distributional and ecological characteristics of molluscan species and individuals.

Results: The results of the present study indicated 44 species and 1287 individuals belonging to 33 families of Mollusca. $T$. distorta and C. gibba, which are particularly indicative of pollution, were found uncommon in the study area and stations. $T$. communis was found to be the most dominant $(45 \%)$. With regard to mollusca species, in particular the fish farm was found to have no discernible negative effect at the sampling sites.

Interpretation: Live fauna that were found inside and above the sediments at the sea bottom can be used as a decisive factor in fishery and aquaculture activities.
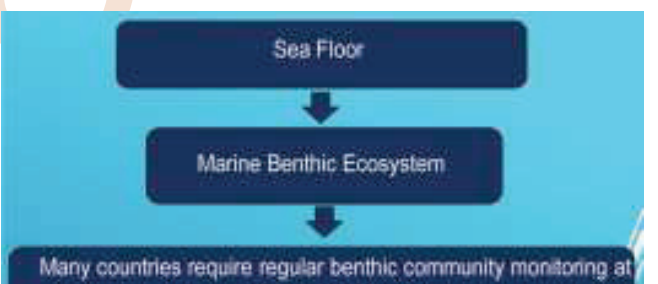
aquaculture farms

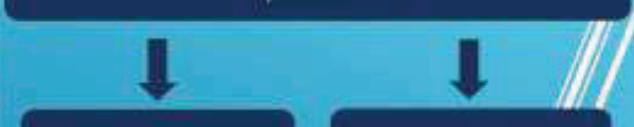

Environmental Monitoring Offishore cage Systems
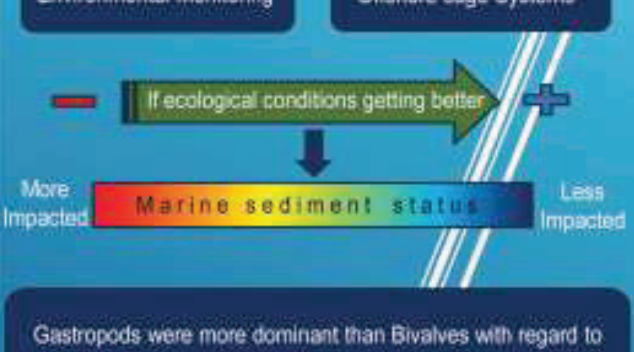
the number of individuals and species.

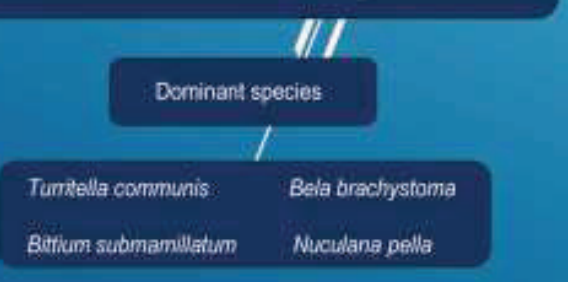

Kew Words : Aegean Sea, Cluster, Environmental evaluation, Molluscan biodiversity, Offshore cage

How to cite : Culha, M., H. Somek and O. Aksoy: Impact of offshore aquaculture on molluscan biodiversity in Ildır Bay, Aegean Sea, Turkey. J. Environ. Biol., 40, 76-83 (2019). 


\section{Introduction}

Marine fish cage culture in the Mediterranean region expanded in a rapid process in 1980s, mainly in the coast of Spain and Greece, when a growing number of farms began producing sea fishes. All the Mediterranean countries where sea cage culture is more common need an evaluation of environmental effects which is used by the authoritatives when comfirming a project bidding process (Cardia and Lovatelli, 2007). The impact of marine aquaculture on the benthic group is of environmental concern (Aguado-Giménez et al., 2011; Paik et al., 2008). The accumulation of waste from aquaculture activity below cages and geochemical differences can cause modification to all kinds of benthic fauna that live on or in the sediments. Changes in benthic groups due to environmental impact is directly attributable to offshore aquaculture farming and needs further attention (Sivadas et al., 2012). For this reason, in USA the impact of fish farms on the benthic community have been determined as one of the most crucial regions requiring more biodiversity research in the future (Price and Morris, 2013). In addition, many coastal countries need monitoring of the benthic structure in aquaculture farms at regular intervals, as a part of their regulatory processes.

Offshore marine cage culture is an ongoing commercial enterprise in many countries. The main objective of offshore pisciculture is to benefit from the best environmental situations found far away from seashore while reducing overlaps with other user activities and avoiding several adverse conditions associated with seaside environments. Offshore marine cage farms encounter seasonal hazards from potential colossal storms and weather cyclone in many regions (Lutz, 2013).

Benthic molluscan have been widely used in monitoring studies of various pollutants globally because of their economic and ecological significance (Mutlu and Ergev, 2012). Also, molluscs have been used as descriptors of benthic association with regard to their ecological relationship to variations in water quality in the Mediterranean Sea (Zenetos, 1996; Rueda et al., 2001; Mutlu and Ergev, 2012). Furthermore, according to dietary diversity, benthic organisms can supply a link between the substratum and living organisms in the water column.

Studies of the Molluscan fauna (Gastropoda-Bivalvia) in the coastal waters of Aegean Sea, Turkey, has been previously reported (Ozturk et al., 2014; Bitlis Bakır et al., 2016; Bitlis et al., 2017). However, until recently, there has been a certain number of researches in Ildır Bay on molluscan species (Sunlu and Orcun, 2007; Dogan et al., 2007; Kırkım et al., 2013).

Considering the continued growth of new offshore fish farms established in the Mediterranean, it is exigence to describe environmental effects of this sector so as to simplify the sustainable improvement of marine fishery (Aksu et al., 2016). However, studies related to the effects of macrobentic organisms living on and in the sediment in offshore conditions are currently insufficient. In view of the above, a study was carried out to investigate the significance of sedimentary or benthic biodiversity in aquaculture activities, and to evaluate whether species loss have a major impact on ecosystem health and ecosystem services that oceans provide.

\section{Materials and Methods}

The benthic samplings of the zoobenthic organisms in the study area were performed by means of a Van Veen grab (10 I) from the sea sediment. Macrobenthic samples were collected during specific months (February, April, August and November) from four stations (St. 1; St. 2; St. 3 and St. 4) having a sandy mud bottom structure from 55 to $67 \mathrm{~m}$ depth (Fig.1).

All benthic samples on the boat deck were sieved through a $0.5 \mathrm{~mm}$ mesh-sized sieve. The remaining material left on the sieve was fixed with $4 \%$ formaldehyde sea water solution. In the laboratory, macrobenthic organisms were separated into main taxonomic categories using a binocular stereomicroscope (Olympus SZ60), and then identified at the species level and counted. Identification was performed according to shell characteristics, and the systematic status of the species were determined using several references (Sabelli et al., 1990; Clemam, 2017). Individual counts of the number of identified species were also carried out. To evaluate the data obtained, various statistical methods were applied to establish the distributional and ecological characteristics of those species and individuals. The results of Soyer's Frequency Index Formula (Soyer, 1970) and Bellan-Santini's Dominance Index Formula (Bellan-Santini, 1969) were displayed in a graphical form. The clustering technique (Cluster) and nMDS (Nonparametric Multidimensional Scaling) were applied to the quantitative data in order to analyse the dissimilarities or similarities between the samples $(n=16)$ and stations according to Molluscan biodiversity. The square root transformation was performed on species

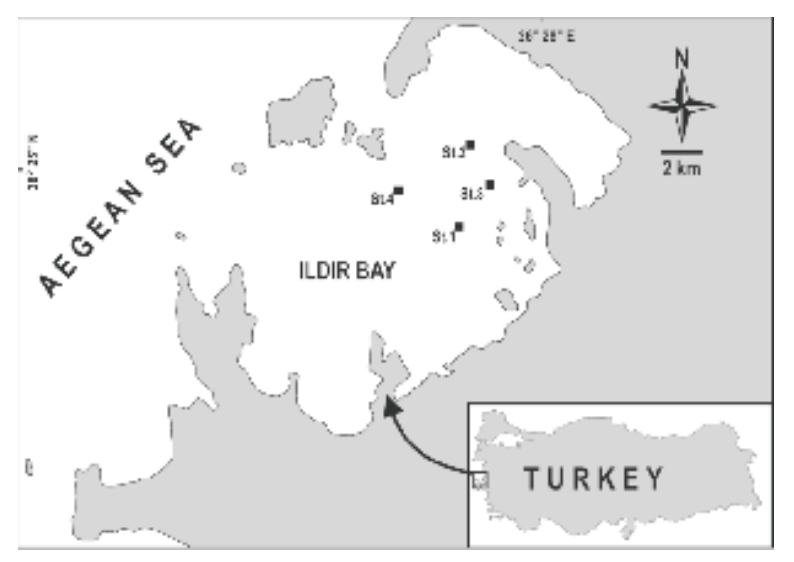

Fig. 1 : Ildır Bay, showing the locations in four sampling stations. 
abundance data for the purpose of normalizing the data and decreasing the weight of extremely dominant species. All analyses were performed with the Primer v5.

Additionally, the physico-chemical parameters of the sampling stations were measured in situ seasonally from surface and bottom water samples, using a WTW Multi 3420 water quality meter probe. For estimating temperature, dissolved $\mathrm{O}_{2}, \mathrm{pH}$, salinity and conductivity of seawater, water samples were also taken by means of Nansen bottles at each of the four stations. The phytoplankton composition in the aquatic environment was also observed. For this purpose, surface water samples of 5 I volume were collected from the study sites and the species were identified according to relevant literature (Cupp, 1943; Dolan et al., 2013).

\section{Results and Discussion}

To provide information about the region and stations at Ildır Bay, some physico-chemical parameters of the surface and bottom water samples were measured in situ at the stations. The mean temperature values were 14.1 (winter, St. 4 ) and $26.4^{\circ} \mathrm{C}$ (summer, St. 4) for the bottom and surface water. The mean dissolved oxygen values were 8.19 (autumn, St. 3) and $9.61 \mathrm{mgl}^{-1}$ (winter, St.4) for the bottom and surface water. The mean $\mathrm{pH}$ values were 8.38 (winter, St. 1) and 8.81 (autumn, St.1) for the bottom and surface water, respectively. In addition, the mean salinity values were $38.3 \%$ (summer, St. 3) and 39.4\%o (spring, St. 4) for the surface and bottom water, respectively. Differing with regard to depth, the temperature and salinity values of the surface water were found to be higher than for the bottom water at all the stations. $\mathrm{pH}$ values did not vary with depth. Only the value of dissolved oxygen of the underside water was found to be higher than the surface water at all the stations. Basaran et al. (2007) and Aksu et al. (2010, 2016) also measured some physicochemical parameters at IIdır and Gerence Bays. They found values close to the parameters found in this study.

As a result of sample evaluation, 44 species and 1287 individuals belonging to 33 families were identified during this study (Table 1). Among these, gastropoda presented the largest number (30 taxon and 1053 individuals) of species and individuals, while bivalvia presented the smallest number (14 taxon and 234 individuals) of species and individuals. In addition, 31 phytoplankton species consisting of three systematic groups (Dinophyceae, Bacillariophyceae and Ciliata) were identified (Carmelo, 1997). In addition, no bloom-forming species were observed near the cages during the study period.

The study carried out at IIır Bay revealed that the Pyramidellidae family had the highest number of species (four species with a dominance value of $12 \%$ ), followed by the Mangeliidae and Eulimidae families with three species each (a dominance value of $9 \%$ ), and then the Cerithidae, Retusidae, Nuculidae and Lucinidae families with two species each (a dominance value of $6 \%$ ) (Fig. 2). In terms of the number of individuals, the Turritellidae family presented the highest number of individuals with 580 and a dominance value of $45 \%$, followed by Cerithidae as the second highest with 112 individuals and a dominance value of $9 \%$ (Fig. 3 ).

When the results of the distribution of these species, according to the stations and seasons, were evaluated, the highest number of species was observed during spring season at station 2 (23 species), but the lowest value was observed during spring at station 1 (8 species) (Fig. 4). In terms of the number of individuals, the highest number of individuals was observed in spring at station 1 (149 individuals), but the lowest value was found in winter at station 1 (30 individuals) (Fig. 5).

Among the 44 species of molluscan collected, Turritella communis was found to have the highest dominance value (45\%)

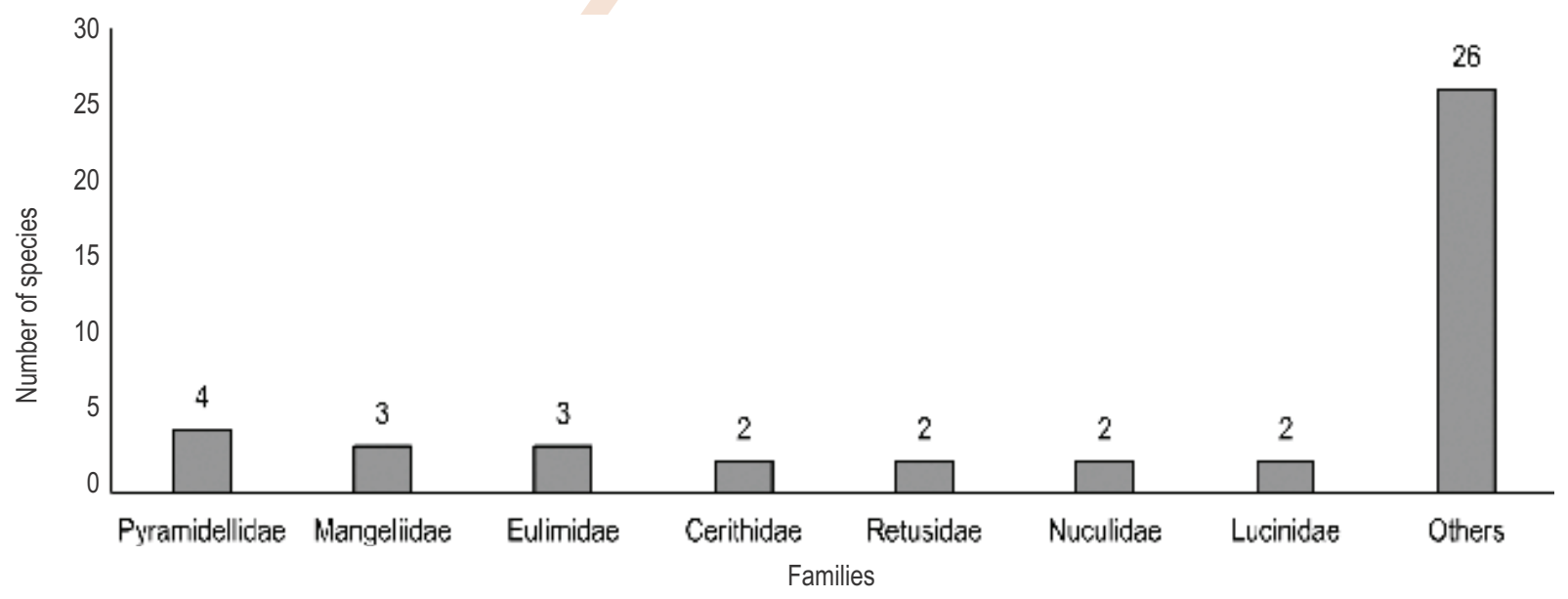

Fig. 2 : Number of species in each family. 
Table 1 : List of the molluscan species identified during the study

\begin{tabular}{|c|c|c|c|c|c|c|c|c|c|c|c|c|c|c|c|c|}
\hline \multirow{2}{*}{$\begin{array}{l}\text { Seasons } \\
\text { Stations }\end{array}$} & \multicolumn{4}{|c|}{ WINTER } & \multicolumn{4}{|c|}{ SPRING } & \multicolumn{4}{|c|}{ SUMMER } & \multicolumn{4}{|c|}{ AUTUMN } \\
\hline & 1 & 2 & 3 & $\mathbf{R}^{\star}$ & 1 & 2 & 3 & $\mathbf{R}$ & 1 & 2 & 3 & $\mathbf{R}$ & 1 & 2 & 3 & $\mathbf{R}$ \\
\hline \multicolumn{17}{|l|}{ Taxon } \\
\hline \multicolumn{17}{|l|}{ Gastropoda } \\
\hline Bittium reticulatum (da Costa, 1778) & 1 & & & & & 2 & & 1 & & & & & 1 & & & 3 \\
\hline Bittium submamillatum (de Rayneval \& Ponzi 1854) & & & 4 & & & 22 & 3 & & & 14 & 25 & & & 4 & 25 & 7 \\
\hline Turritella communis (Risso, 1826) & 10 & 36 & 14 & 18 & 114 & 45 & 55 & 27 & 15 & 70 & 32 & 26 & 30 & 38 & 10 & 40 \\
\hline Marshallora adversa (Montagu, 1803) & 1 & 1 & & & 2 & & 2 & & 4 & & 3 & & & 1 & & \\
\hline Cerithiopsis tubercularis (Montagu, 1803) & & & & 2 & & 2 & & & & & & & & & & \\
\hline Epitonium muricatum (Risso, 1826) & & & 2 & & & 3 & & 2 & & & & 4 & & & & 1 \\
\hline Eulima glabra (Da Costa, 1778) & 2 & 3 & 7 & 1 & & 3 & & 2 & & 1 & 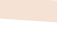 & 3 & & 3 & & 1 \\
\hline Eulima sp. & & & 1 & & & & & & & & & & & & & \\
\hline Vitreolina curva (Monterosato, 1874) & & & & & & & & & 1 & & & & & & & \\
\hline Alvania punctura (Montagu, 1803) & & & 1 & 5 & & 11 & & & & & 3 & 4 & & 1 & & \\
\hline Hyala vitrea (Montagu, 1803) & & & 1 & 2 & & 3 & & 2 & 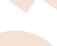 & 7 & & & & 2 & & 2 \\
\hline Aporrhais pespelecani (Linnaéus, 1758) & & & & & 2 & & & & 5 & 4 & & & & 2 & & \\
\hline Calyptraea chinensis (Linnaéus, 1758) & 1 & 2 & & 1 & & & 1 & & & 7 & & & & 3 & & 4 \\
\hline Euspira nitida (Donovan, 1804) & 1 & 1 & & & & 2 & & & 1 & & & 1 & & 3 & & \\
\hline Bolinus brandaris (Linnaéus, 1758) & & 2 & & & & & & & & & & & & & & \\
\hline Bela brachystoma (Philippi, 1844) & 1 & 4 & 12 & 1 & 4 & 7 & 9 & 3 & 2 & & 3 & 9 & 1 & 8 & 1 & 4 \\
\hline Mangelia costulata (Blainville, 1829) & 1 & & 3 & 2 & & & 7 & & 3 & & 3 & 4 & 2 & & 1 & \\
\hline Mangelia unifasciata (Deshayes, 1835) & & & & & & 1 & & & & 2 & & & & & & \\
\hline Raphitoma echinata (Brocchi, 1814) & & & & & & 1 & & & & & 2 & & & & & \\
\hline Ammonicera fischeriana (Monterosato, 1869) & & 1 & & & & & & & & & & & & & & \\
\hline Eulimella acicula (Philippi, 1836) & 2 & & 1 & & & & 1 & & & & 3 & & & 2 & & 1 \\
\hline Megastomia conoidea (Brocchi, 1814) & & & 3 & & & 4 & & & 1 & & & & 2 & & 1 & \\
\hline Odostomia acuta (Jeffreys, 1848) & & 1 & & & & 1 & & & & & & & & & & \\
\hline Turbonilla acutissima (Monterosato, 1884) & & 3 & & 1 & & & 1 & & & & 1 & & 2 & 7 & 1 & 3 \\
\hline Ebala pointeli (de Folin, 1868) & & & & & & 1 & & & & & & & & & 2 & \\
\hline Acteon tornatilis (Linnaeus, 1758) & & & & & & & 2 & & 1 & & 3 & & 1 & & & \\
\hline Ringicula auriculata (Ménard de la Groye, 1811) & 2 & & 7 & & & & & & & & & & 2 & & 1 & \\
\hline Cylichna cylindracea (Pennant, 1777) & 1 & & 7 & 2 & & & 1 & & & & & & & & & \\
\hline Pyrunculus hoernesii (Weinkauff, 1866) & 1 & & 1 & & & 1 & & & & & & & & & & \\
\hline Retusa minutissima (Monterosato, 1878) & & & & & & 12 & & 5 & & & 8 & & & 11 & & \\
\hline Bivalvia & & & & & & & & & & & & & & & & \\
\hline Nucula nucleus (Linnaeus, 1758) & & & & & & & 12 & & 5 & & 6 & & & & & \\
\hline Nuculana pella (Linnaeus, 1767) & & & & & & & 17 & & 15 & & & 6 & & & 12 & \\
\hline Musculus costulatus (Risso, 1826) & & & & & & 1 & & & & & 2 & & & & & \\
\hline Pinctada radiata (Leach, 1814) & & & & 1 & & & & & & & & & & & & \\
\hline Anomia ephippium (Linnaeus, 1758) & & 2 & & & & & & & & & & & & & & \\
\hline Ostrea edulis (Linnaéus, 1758) & & & & & & & & & & 1 & & & & & & \\
\hline Loripinus fragilis (Philippi, 1836) & & & & 1 & 14 & 5 & & & 6 & & 5 & & & & & \\
\hline Myrtea spinifera (Montagu, 1803) & 2 & 1 & 7 & 4 & 5 & 2 & 3 & & 2 & 1 & 7 & & 3 & 1 & 2 & 4 \\
\hline Plagiocardium papillosum (Poli, 1791) & & 1 & & & & 2 & & & & & & & & & & \\
\hline Tellina pulchella (Lamarck, 1818) & & & & & & 1 & & 3 & & & & & & & & \\
\hline Abra alba (Wood W., 1802) & 2 & & 1 & & 6 & & 5 & & & & & & & & & \\
\hline Corbula gibba (Olivi, 1792) & 1 & 4 & 2 & 6 & & 3 & 2 & 7 & & 2 & 3 & 8 & 3 & 1 & 2 & 4 \\
\hline Hiatella arctica (Linnaeus, 1767) & & & & & & & 2 & & 1 & & & & & & & \\
\hline Cuspidaria rostrata (Spengler, 1793) & 1 & & 1 & & & & 1 & & & & & & & & & \\
\hline
\end{tabular}

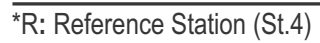

with 580 individuals. The other dominant mollusca species were Bittium submamillatum (104 individuals, 8\%), Bela brachystoma
(69 individuals, 5\%), Nucula pella (50 individuals, 4\%), Corbula gibba (48 individuals, 4\%), Myrtea spinifera (44 individuals, 3\%) 


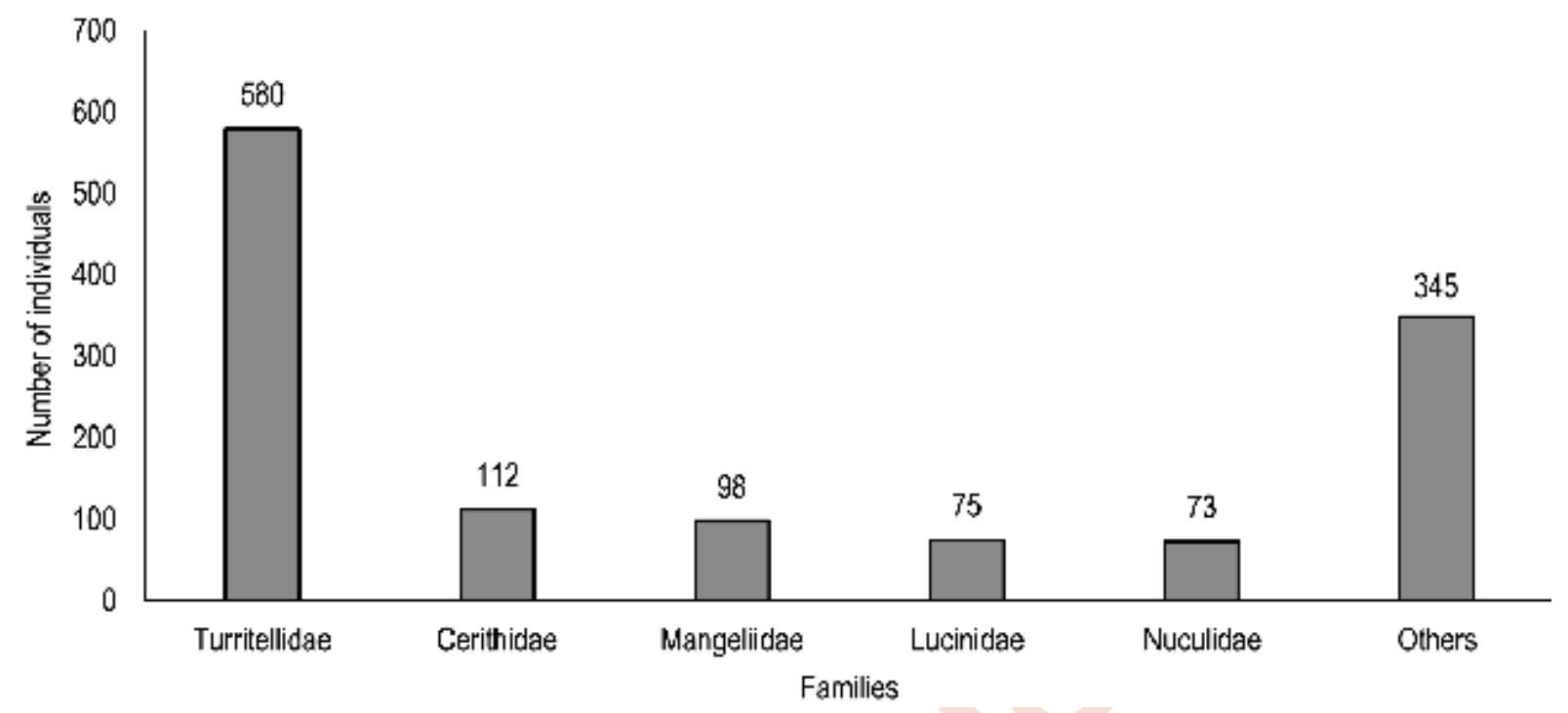

Fig. 3 : Number of individuals in each family.

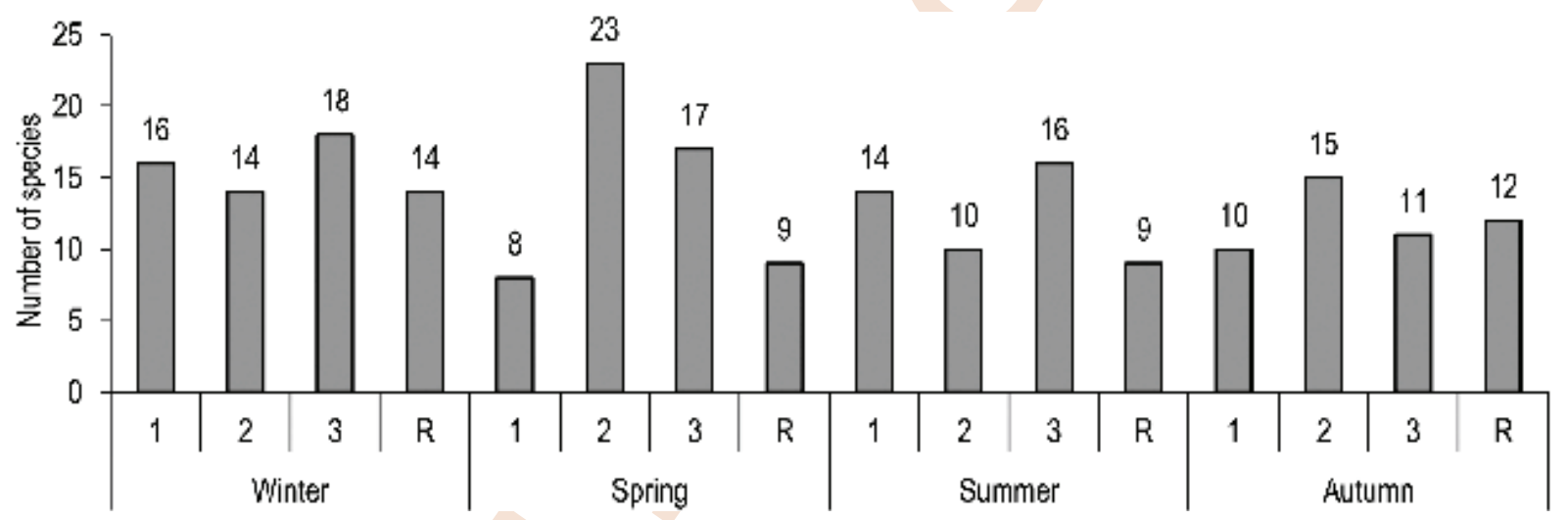

Fig. 4 : Number of species found at stations and seasons.

and other groups (392 individuals, 31\%).

The frequency of the identified molluscan species in the study area were evaluated according to Soyer's Frequency Index Formula and, as a result, 34 species were grouped as 'continuous' and 10 species (Eulima sp., V. curva, B. brandaris, $M$. unifasciata, A. fischeriana, O. acuta, $P$. radiata, $A$. ephippium, 0. Edulis and $P$. papillosum) as 'common'. Also, no species was classified as 'rare' in the frequency index evaluation, because there were less than five stations in this study (Fig. 6).

According to the distribution and abundance of the Molluscan species identified at the study sites, the similarities between the stations were shown in Fig. 7 as Cluster and nMDS dendogram graphics. When these graphs were evaluated, the similarities between the reference stations and other stations were mostly over 40 percent and no obvious grouping was identified among the samples.

Benthic molluscan have been evaluated as identifiers of sublittoral soft bottom benthic group related to their ecological relationship to marine water quality differentiations in the Mediterranean Sea (Mutlu and Ergev 2012; Zenetos 1996). Furthermore, according to dietary diversity, benthic organisms can supply a link between substratum and living organisms in the water column. These organisms are an important source of nutrients, especially for deep fishes (Albayrak et al., 2007).

Offshore marine farms are established in depths between 10 and $50 \mathrm{~m}$, especially in sheltered areas off the open sea which are visible coastline (Aksu et al., 2016). The environmental effects of offshore fish farming differ with regard to farm management 


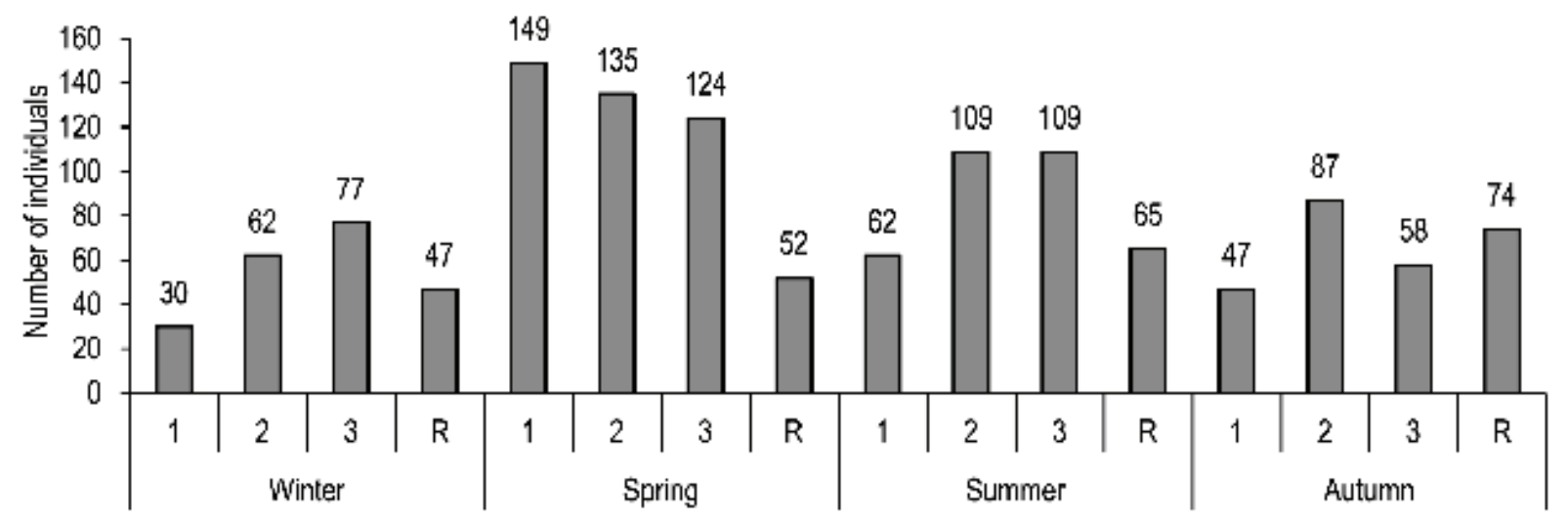

Fig. 5 : Number of individuals found at stations and seasons.

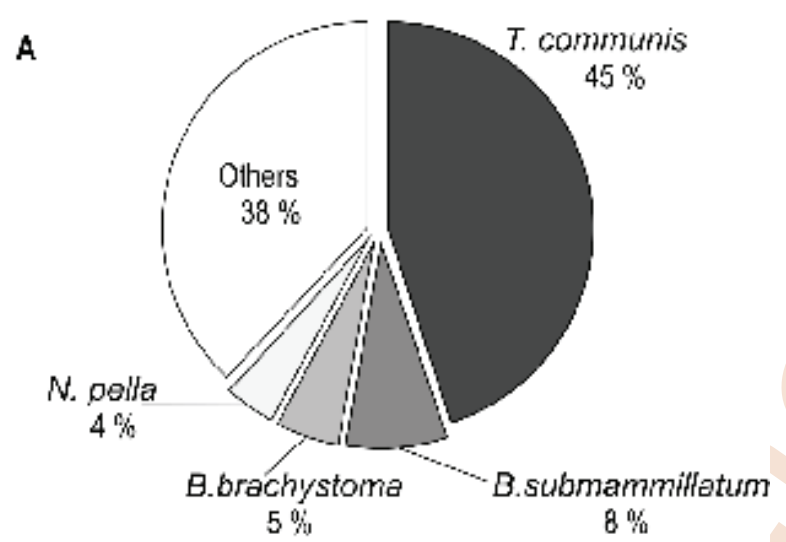

B

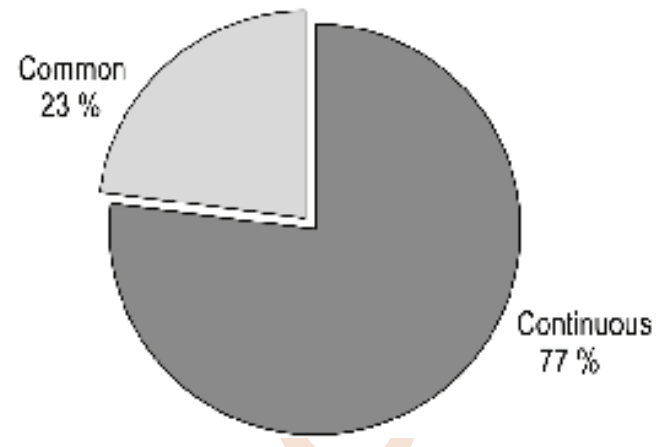

Fig. 6 : Dominance (A) and frequency index values (B) of mollusca species.

style, type of feeding, fish density and hydrographical conditions of the region $(\mathrm{Wu}, 1995)$. One of the most important influence of aquaculture on marine ecosystem is the uneaten baits by fishes. Their faeces accumulate beneath the cages, leaving sediment whose organic carbon concentration is one of the significant factors in defining the mineral quality (Karakassıs et al., 2000; Hyland et al., 2005). Also, as a result of accumulation of unconsumed fish feeds on the seabed, the structure of sediment can be changed (Mangion et al., 2014).

Soft sediment communities have high amount of organic carbon. So the biodiversity related to benthic macrofauna is usually low (Hyland et al., 2005). However, in this study ordinary species richness was observed in the area, especially in terms of mollusca, and no discernible negative effect of the fish farm was determined in sampling sites including the reference station. Benthic scavengers in the Mediterranean contribute to eliminate deposited organic leftovers on the benthic zone (Vizzini and Mazzola, 2012). Vita and Marin (2007) established that the sixmonth fallow period was not enough time for full recovery of benthic communities beneath offshore cages at the marine farm (Mangion et al., 2014).

In the soft bottom sediments of the marine ecosystem, knowledge about time and region-specific changes of benthic organisms is quite valuable for clarifing both biotic and abiotic mutual effect (Dauvin et al., 2004). Hydrographical, sediment structure and biological varieties are most likely to be timedependent controlling agents of the benthic society in marine shallow waters (Gray, 1981; Karakassis and Eleftheriou, 1997).

Molluscan have an important position in the structure of the ecosystem and conservation of biodiversity (Zenetos, 1996). In the study, among the 44 species, Mollusca species such as $T$. distorta and C. gibba, which are particularly indicators of pollution, were found less frequently or infrequently in the study area. Also, T. communis was found to have the highest dominance value with 580 individuals (45\%). This situation can be explained as a result of these species being dominant which can create an enormous population both in terms of depth and biotope structure (HrsBrenko, 2006). For example, M. galloprovincialis can also create intensive population in semi-dirty zones (Ozturk et al., 2008). The species, known as a pollution indicator, was also intensively encountered in the Aliaga marine ecosystem. The reason for this 


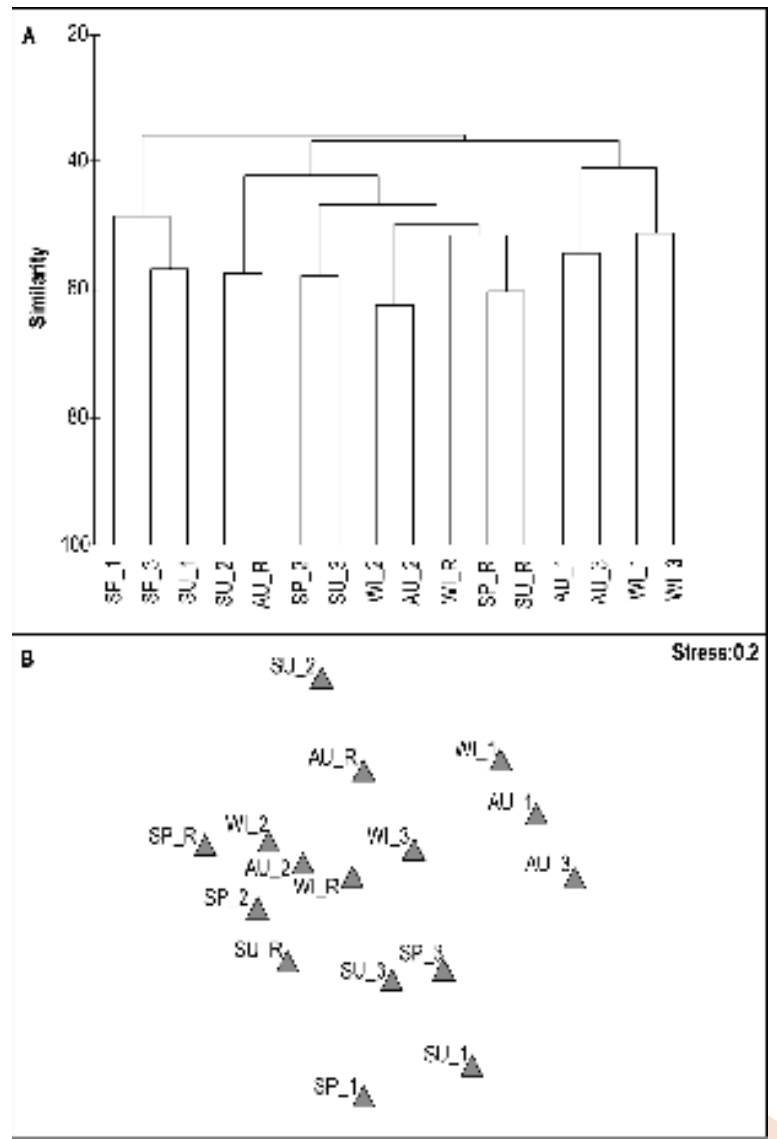

Fig. 7 : Dendrograms of $\mathrm{A}$ : Cluster analysis and $\mathrm{B}$ : Nonparametric multidimensional scaling ordination (nMDS) based on quantitative data belonging to samples $(n=16)$ and stations according to Molluscan biodiversity (WI: Winter, SP: Spring, SU: Summer, AU:Autumn).

situation is that the area contains various industrial and shipyard activities, marine transportation and wastewaters discharged in Candarlı Bay (Ergen et al., 1994).

The number of species reported in previous studies were different from those present in the Turkish seas due to different depths, biotopes and stations studied, and also using different sampling materials such as dredge, gravity corer, grab etc. Considering prior studies, many of the species identified in the present study were common and well-known species near the Turkish coasts (Dogan et al., 2007; Ozturk et al., 2014; Bitlis Bakır et al., 2016; Bitlis et al., 2017).

Live fauna found inside and above the sediments at sea bottom can be used as a decisive factor in fishery and aquaculture activities. This study has contributed to the study of Molluscan biodiversity. It can be stated that the existing fish farm did not have a significiant adverse effect on the region. Over dense fishing activities may cause changes in the structure of marine living environment and can give shape to the biodiversity, habitat character, biological live weight (biomass) and productivity related to biota. Finally, it is important that the benthic fauna is monitored at regular intervals in order to promote a sustainable marine ecosystem.

\section{Acknowledgments}

The authors would like to thank Camlı Yem Besicilik, Sanayi ve Ticaret A.S., PInar Balık (Fish hatchery and aquaculture farm), as well as Operations Manager Salih Koseler and Managing Director Uzay Senturk for their support and assistance in this study and for their appreciation of the benefits to be gained from independent research. Special thanks also go to Aqua. Eng. Tuncay Sevinc. We also thank Dr. Aydın Unluoglu for computerizing the data using the Primer $\vee$ packet program.

\section{References}

Aguado-Giménez, F., M.A. Piedecausa, C. Carrasco, J.M. Gutiérrez, V. Aliaga and B. García-García: Do benthic biofilters contribute to sustainability and restoration of the benthic environment impacted by offshore cage finfish aquaculture. Mar. Poll. Bull., 62, 1714-1724 (2011).

Aksu, M., A.K. Basaran and O. Egemen: Long-term monitoring of the impact of a capture-based bluefin tuna aquaculture on water column nutrient levels in the Eastern Aegean Sea, Turkey. Environ. Monit. Assess., 171, 681-688 (2010).

Aksu, M., A. Kaymakcı Basaran and O. Egemen: Effects of off-coast bluefin tuna fattening on water quality in the Eastern Mediterranean Sea. Turk. J. Fish. Aquat. Sci., 16, 855-863 (2016).

Albayrak, S., H. Balkıs and M.E. Cınar: Shallow-water soft bottom macrozoobenthic communities from Edremit Bay (NE Aegean Sea). Belg. J. Zool.,137, 127-132 (2007).

Basaran, A.K., M. Aksu and O. Egemen: Monitoring the impacts of the offshore cage fish farm on water quality located in Ildir Bay (IzmirAegean Sea). J. Agri. Sci., 13, 22-28 (2007).

Bellan-Santini, D.: Floristic and faunistic study of some infralittoral stands of bedrock. Rec. Trav. St. Mar. End., 26, 237-298 (1969).

Bitlis Bakır, B., B. Ozturk, A. Dogan and N.Turkcu: Temporal variation of the soft-bottom molluscan fauna in Northwestern Iskenderun Bay (Levantine Sea). Oceanologi. Hydrobiologi. Studies, 45, 445-452 (2016).

Bitlis, B., B. Ozturk and A. Dogan: Contribution to the knowledge of the molluscan fauna of Kuşadası Bay (Aegean Sea). Turk. J. Zool., 41, 980-990 (2017).

Cardia, F. and A. Lovatelli: A review of cage aquaculture: Mediterranean Sea. In: Cage aquaculture; Regional Reviews and Global Overview (Eds.: M. Halwart, D. Soto and J.R. Arthur). FAO Fisheries Technical Paper, No. 498, Rome, FAO. 241 (2007).

Carmelo, R.T.: Identifying Marine Phytoplankton. Academic Press, USA, pp. 858 (1997).

Clemam: Check List of European Marine Mollusca, http://www.somali. asso.fr/clemam/index.clemam.html, Accessed on May, (2017).

Cupp, E.E.: Marine plankton diatoms of the west coast of North America. Bull. Scripps Instn. Oceanogr., 5, 1-237 (1943).

Dauvin, J.C., E. Thiebaut, J.L. Gomez Gesteıra, K. Ghertsos, F. Gentil, 
M. Ropert and B. Sylvand: Spatial structure of a subtidal macrobenthic community in the Bay of Veys (Western Bay of Seine, English Channel). J. Exp. Mar. Biol. Ecol., 307, 217-235 (2004).

Dogan, A., M. Onen and B. Ozturk: Bivalvia (Mollusca) Fauna of Ilır Bay (Izmir-Cesme). Turk. J. Aquat. Life, 5-8, 27-35(2007).

Dolan, J.R., D.J.S. Montagnes, S. Agatha, D.W. Coats and D.K. Stoecker: The biology and ecology of tintinnid ciliates: Models for marine plankton. Chichester, United Kingdom, p. 296 (2013).

Ergen, Z., A. Kocatas, T. Katagan and M.E. Cinar: The benthic fauna of Gencelli Bay (Aliaga Izmir). 1'st National Congress on Ecology and Environment. E.U. J. Facul. Sci., Bornova, pp.1047-1059 (1994).

Gray, J.S.: The Ecology of Marine Sediments: An Introduction to the Structure and Function of Benthic Communities. Cambridge University Press, London, pp. $42-47$ (1981).

Hrs-Brenko, M.: The basket shell, Corbula gibba Olivi, 1792 (Bivalve Mollusks) as a species resistant to environmental disturbances: A review. ActaAdriat., 47, 49-64 (2006).

Hyland, J., L. Balthis, I. Karakassis, P. Magni, A. Petrov, J. Shine, O. Vestergaard and R. Warwick: Organic carbon content of sediments as an indicator of stress in marine benthos. Mar. Ecol. Prog. Ser., 295, 91-103 (2005).

Karakassis, I. and A. Eleftheriou: The continental shelf of Crete: Structure of macrobenthic communities. Mar. Ecol. Prog. Ser., 160, 185-196 (1997).

Karakassis, I., M. Tsapakis, E. Hatziyanni, K.N. Papadopolou and W. Plaiti: Impact of cage farming of fish on the seabed in three Mediterranean coastal areas. ICES J. Mar. Sci., 57, 1462-1471 (2000).

Kırkım, F., M. Onen, O. Egemen, I. Ozel, T. Katagan, T. Koray, B. Ozturk, M.E. Cınar, A. Dogan, L. Yurga, V. Aker, M. Aksu, A. Basaran, E. Daglı, K. Bakır, B. Bitlis Bakır, F. Cevirgen, A. Evcen, S. Koldaguc and A. Tuzen: Fisheries Technical Paper: Seasonal ecological monitoring report of offshore aquaculture enterprise located in the Ildır, Cesme, E.U. Facu. Fisher. Depart. Hydrobiol., Bornova, p. 48 (2013).

Lutz, C.G.: Offshore Aquaculture Production. Louisiana State University. Agr. Cent. 0., 6, 95-113 (2013).

Mangion, M., J.A. Borgh, R. Thompson and P.J. Schembri: Influence of tuna penning activities on soft bottom macrobenthic assemblages. Mar. Poll. Bull., 79, 164-174 (2014).

Mutlu, E. and M.B. Ergev: Distribution of soft-bottom mollusk (Mollusca) in Mersin Bay (Eastern Mediterranean Sea). Turk. J. Zool., 36, pp.430-446 (2012).

Ozturk, B., M. Onen and A. Dogan: Determination atlas of Turkish marine molluscan species, Ankara. The Scientific and Technical Research Council of Turkey (Tubitak) 103T154, 468 (2008).

Ozturk, B., A. Dogan, B. Bitlis Bakır and A. Salman: Marine molluscs of the Turkish coasts: An updated checklist. Turk. J. Zool., 38, 832879 (2014).

Paik, S.G., S.G. Yun, H.S. Park, J.H. Lee and C.W. Ma: Effects of sediment disturbance caused by bridge construction on macrobenthic communities in Asan Bay, Korea. J. Environ Biol., 29, 559-566 (2008).

Price, C.S. and J.A. Morris: Marine cage culture and the environment: Twenty-first century science informing a sustainable industry. Noaa Technical Memorandum Nos Nccos, 164, 158 (2013).

Rueda, J.L., M. Fernandez-Casado, C. Salas and S. Gofas: Seasonality in a taxocoenosis of molluscs from soft-bottom in the Bay of Cadiz (Southern Spain). J. Mar. Biol. Assoc. U.K., 81, 903-912 (2001).

Sabelli, B., R. Giannuzi-Savelli and D. Bedulli: Annotated catalog of marine mollusks of the Mediterranean. Libreria Naturalistica Bolognese, 1, 1-34 (1990).

Soyer, J.: Benthic bionomics of the continental shelf of the Catalan coast of France. III: The stands of Copepods Harpacticoides (Crustacea). Vie Milieu., 21, 377-511 (1970).

Sivadas, S., B. Ingole and A. Sen: Some ecological aspects and potential threats to an intertidal gastropod, Umbonium vestiarium. J. Environ. Biol., 33, 1039-1044 (2012).

Sunlu, U. and E. Orcun: Investigation on impacts of coastal cage aquaculture to aquatic environment in Sıgacık (Seferihisar, Izmir) region. Ege. J. Aqua. Sci., 24, 01-09 (2007).

Vita, R. and A. Marin: Environmental impact of capture-based bluefin tuna aquaculture on benthic communities in the western Mediterranean. Aquacult. Res., 38, 331-339 (2007).

Vizzini, S. and A. Mazzola: Tracking multiple pathways of waste from a northern bluefin tuna farm in a marine-coastal area. Mar. Environ. Res., 77, 103-111(2012).

Wu, R.S.S.: The environmental impact of marine fish culture: Towards a sustainable future. Mar. Poll. Bull., 31, 159-166 (1995).

Zenetos, A.: Classification and interpretation of the established Mediterranean biocoenoses based solely on bivalve molluscs. J. Mar. Biol.Assoc. U.K., 76, 403-416 (1996). 